\title{
メンブレン型バネ構造を持つ振動ジャイロのバネ設計に関する一考察
}

\author{
正員 前 中一介（姫路工大）、非会員岡田茂（姬路工大）、 \\ 非会員 德 永 理 人 (姬路工大)、学生員藤 田 孝 之(姫路工大)、 \\ 非会員 前田宗 雄 (姫路工大)
}

\section{A Study of Vibratory Gyroscope using Membrane Structure as A Spring}

Kazusuke Maenaka, Member, Shigeru Okada, Student Member, Masato Tokunaga, Member, Takayuki Fujita, Student Member, Muneo Maeda, Nonmember (Himeji Institute of Technology)

\begin{abstract}
Recently, micromachined vibratory gyroscopes are in the lime light. Especially, the double resonant mode is important in order to improve the sensitivity of micro gyroscopes. For such a purpose, some membrane structure of the micromachined gyroscopes have been reported. In this paper, we show the design strategy of the membrane spring for noting the resonance characteristics. In the paper, by measuring the fabricated devices and some simulations, we pointed out that the through knowledge of a nonlinearity of the membrane spring is important for micro structures.
\end{abstract}

キーワード：振動ジャイロ、バネ、双共振、メンブレン、SOI

\section{1.はじめに}

近年、メンブレン棈造をバネとして用いる振動型ジヤイ 口の提案がなされている(1)。これらのデバイスでは90度回転 対称構造をマスク精度で実現できるため、励振方向の共振 周波数と検出方向の共振周波数をコントロールしやすく、 双共振(を用いたデバイスに対して大きなメリットがある。

これまで提案されてきたデバイスでは、メンブレン構造 が比較的大きな金属板であったり、また、メンブレンの変 位をあまりとらない構成のものであったが、マイクロ化、 高感度化のためには小型メンブレンを大変位させた場合の 挙動に関する考察が重要である。本論文ではシリコンマイ クロマシニングを用いて試作したメンブレンによるバネ構 造について、特にその構造非線形性による共振特性の振る 舞いを実験扣よびシミュレーションで調查し、マイクロマ シニングでこのようなデバイスを設計する際の知見を得な ので報告する。

\section{2. メンブレンタイプ振動ジャイロの棈造・動作原理}

図1にメンブレンタイプの振動ジヤイロの構造例を示 す。この例では十字型に形成されたメンブレン状バネ構造 体の中央にマスがあり、これを参照振動としてx方向に、 例之ば磁界電流相互作用により振動させる。 速度が印加すると、振動するマスに $\mathrm{y}$ 方向のコリオリカが 発生し、マスはy 方向に参照振動と同期して変位する。こ の変位を検出すれば与えられた角速度を知ることができ る。このような構造では、駆動方向、検出方向の共振周波

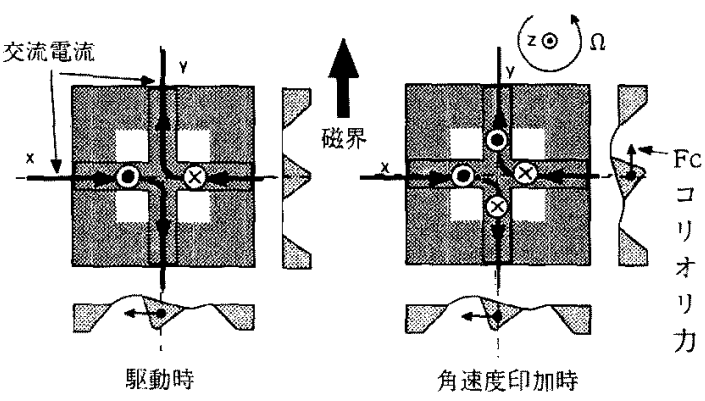

図 1 デバイス構造例

Fig. 1. Example of device structure.

数はマスク精度でほぼ決定可能であるため、両者を一致さ せ双共振による高感度化(2)を望むことができる。しかしなが ら、参照振動として大変位を与えた場合、いわゆるハード スプリング効果によってその共振周波数が変化し、適切な 駆動周波数を得ることができない。以下、具体的なデバイ ス例をとりあげ、検討した結果について述べる。

\section{3. 試作したデバイス例と測定方法}

図 2 に試作したデバイス 2 例の概略を示す。図 2 Aは、 メンブレンバネ形状を十字棈造としたもの、図 2 Bは構 造としたものである。両者ともにメンブレンの部分の厚さ は $5 \mu \mathrm{m}$ 、マスとなる部分の厚さ (ウエハ厚) は $625 \mu \mathrm{m}$ であ る。基板にはSOIを用い、表層シリコン層がメンブレンとな るようにプロセスを組み立てた。また、マスを基板から切 り離すプロセスとしてICPRIEを用いており、マスの部分は ほとんど正確な直方体である。 
メンブレン・マスで形成される共振系の特性を計測する ため、デバイスをピエゾアクチュエータに貼り付け、 $\mathrm{x}$ 方 向に駆動した。この際バネの $\mathrm{z}$ 方向の変位を、各メンブレ
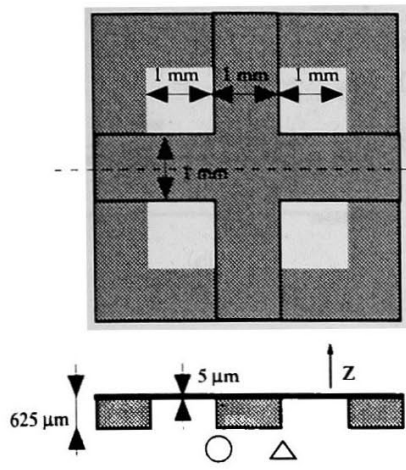

A 十字構造
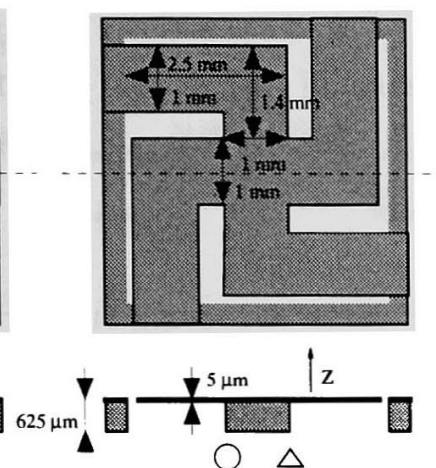

B 杜構造

図 2 評価したデバイス

Fig. 2. Test devices.
ンバネ中央部にレーザ変位計のスポットをあて計測した。

\section{4. 評価および考察}

十字構造、民構造の両者に対し、駆動振幅をパラメータ にして共振特性を計測した。図 3 に計測結果を示す。グラ フは微小振幅で駆動したときの共振周波数で規格化した駆 動周波数を横軸に、メンブレン部の振幅を縦軸に示してい る。両者ともに、計測範囲では駆動変位振幅が大きくなる とともに共振周波数が高周波側に変化する、ハードスプリ ング効果が現れている。特に十字型構造の場合、振幅の大 きなところで必ずしも駆動振幅と最大振動振幅が比例して いない部分がある。これはハードスプリング効果特有の最 大振幅値付近での振動の不安定性が発現しているためであ る。両者のグラフを比較したとき、ハードスプリング効果 に明らかな差異が見られる。この事実を定量的に説明する ため、構造非線形性を加味したFEM解析(ANSYSによる)に よって静的な変位におけるバネ定数の变化を計算した。図 4 か解析結果である。解析ではマスの両端(図 2 で、○部 $\Delta$ 部)にそれぞれ $\pm z$ 軸方向の荷重を与えトルクを発生させ、 その点の変位を計算している。図 4 では第 0 次近似とし て、変位xを得るために与えた荷重Fにより、平均的バネ定 数 $\mathrm{F} / \mathrm{x}$ を計算し、これを併せて表示している。共振周波数が 一般的 2 次系の共振構造で記述できるとすれば、それはバ 交定数の平方根に比例するはずである。このようにして求 めた変位と共振周波数の関係をプロットしたものが、図 3 のグラフのポイント(「計算值」と記されている)である。極 めて荒い近似でありながら、計算結果は計測結果を良く表 現していることが分かる。

\section{5. まとめ}

メンブレン構造のバネを持つマイクロ振動型ジャイロに ついて、そのバネ構造と共振特性について実験と計算によ り議論した。その結果、1：比較的薄く、柔らかいと考え
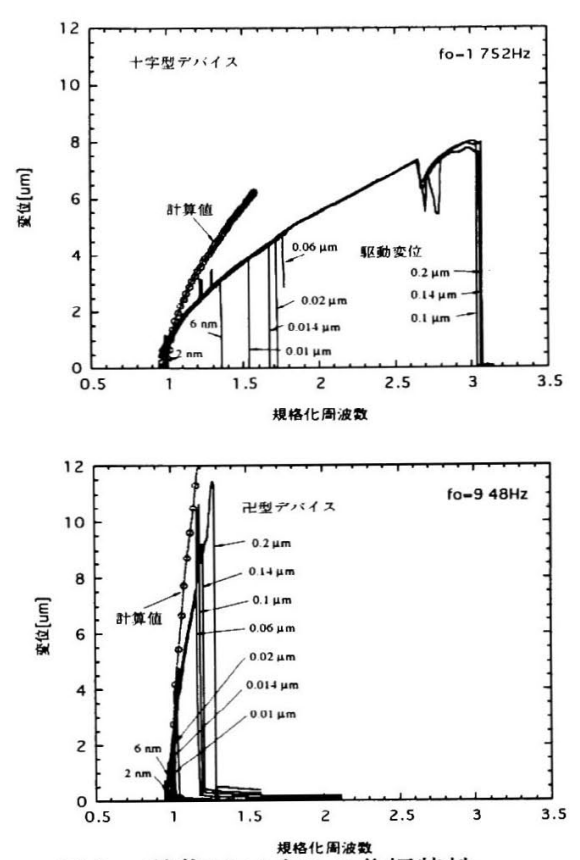

図 3 試作デバイスの共振特性

Fig. 3. Resonance characteristics of test devices.

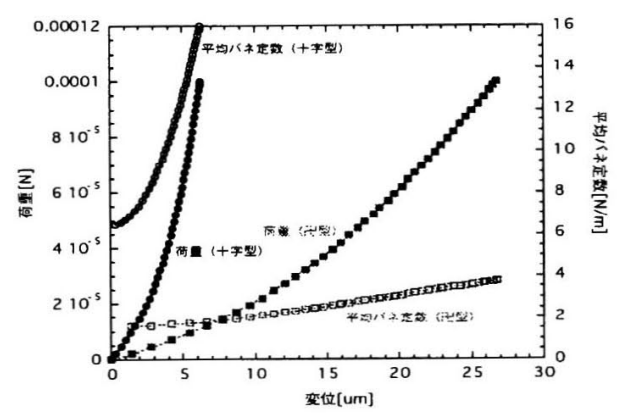

図 4 FEMにより計算したバネ定数

Fig. 4. Calcurated spring constants.

られるメンブレンバネでも、マイクロマシニングで扱うサ イズになるとハードスプリング効果が無視できないこと、 $2:$ この効果はバネの静的非線形性をFEMなどを用いて計 算することによって予測可能であること、 3 : 結果として 特に双共振を用いたデバイスのように共振周波数の制御が 重要であるデバイスではモーダルな解析とともにバネの非 線形効果を十分考慮して構造設計しなければならないこと を明らかにした。

(平成11年 8 月 31 日受付)

\section{文献}

(1) Y.Tomikawa,HOkuyama,A.Satoh,S.SugawaraandK.Ohnishi " Flatly Supported Vibratory Gyro-Sensor Using Trident-Type Tuning Forlk Resonator", Sym. Gyro Technology, Stuttgart, Germany, 8.0 (1997)

(2) 前中一介、藤田孝之、前田宗雄, "振動型マイクロ ジャイロの設計指針", 電学論、Vol.118-E, 377383 (1998) 